\title{
Experimental infection of Penaeus monodon with Taura syndrome virus (TSV)
}

\author{
Thinnarat Srisuvan*, Kathy F. J. Tang, Donald V. Lightner \\ Department of Veterinary Science and Microbiology, University of Arizona, Tucson, Arizona 85721, USA
}

\begin{abstract}
Clinical signs and lesions of Taura syndrome virus (TSV) infection in Penaeus monodon have not been documented although the virus has been detected in this shrimp species by reverse transcription polymerase chain reaction (RT-PCR). This study provides the first evidence of TSV infection in P. monodon by histological and in situ hybridization (ISH) analyses. We performed experimental bioassays with groups of $P$. monodon using inocula of $P$. monodon and Litopenaeus vannamei (Th04PmTSV and Th04LvTSV, respectively), which were collected from Thailand in 2004 and found to be positive for TSV by RT-PCR. Samples of shrimp for histological and ISH analyses were collected on Days 2, 14, and 28 post-inoculation. Mortality among TSV-inoculated P. monodon appeared on Day 3, with 2 out of 10 shrimp dying. Severe necrosis of cuticular epithelial cells and lymphoid organ spheroids, indicative of acute and chronic phase lesions of TSV infection, respectively, were detected in the samples. Sequence analyses of the capsid protein 2 (CP2) gene showed that Th04PmTSV and Th04LvTSV isolates were different; however, both belonged to a phylogenetic family of Asian TSV isolates. The results of this study demonstrated that both mortality and histological lesions are associated with TSV infection in P. monodon.
\end{abstract}

KEY WORDS: Taura syndrome virus · TSV $\cdot$ Penaeus monodon · TSV infection

\section{INTRODUCTION}

Taura syndrome is one of the most important diseases of cultured penaeid shrimp. Since the disease was first described in Ecuador in 1992, it has rapidly spread to many countries of the world (Jimenez 1992, Hasson et al. 1995, 1999a, Lightner et al. 1995, Tu et al. 1999, Yu \& Song 2002). The causative agent is Taura syndrome virus (TSV), which was placed in the family Dicistroviridae (Mayo 2002, 2005). TSV is a nonenveloped, icosahedral virus of $32 \mathrm{~nm}$ in diameter (Bonami et al. 1997). The genome of TSV is a singlestranded positive-sense RNA of 10205 nucleotides and consists of 2 large open reading frames (ORF1 and ORF2) (Mari et al. 2002). ORF1 may code for nonstructural proteins, including helicase, protease, and RNA-dependent RNA polymerase, whereas ORF2 codes for structural proteins such as the 3 major capsid proteins CP1, CP2, and CP3 (Mari et al. 2002).

Taura syndrome is associated with high mortalities in most life stages of Pacific white shrimp Litopenaeus vannamei (Lightner 1996). Other species such as $L$. stylirostris and L. setiferus can also be infected with TSV and exhibit similar clinical signs (Overstreet et al. 1997, Erickson et al. 2002). Recently, TSV was detected in Penaeus monodon by reverse transcription polymerase chain reaction (RT-PCR); however, no clinical signs or lesions characteristic of infection were found (Chang et al. 2004, Nielsen et al. 2005). Diagnosis of TSV infection in P. monodon is important because this species is a predominant species in shrimp aquaculture. In the present study, using histology and in situ hybridization (ISH), we demonstrated that both mortality and histological lesions are associated with TSV infection in P. monodon.

\section{MATERIALS AND METHODS}

Experimental bioassays. During 2004, mortalities were observed in shrimp farms in the provinces of Chachoengsao and Chumporn, Thailand. Shrimp Penaeus monodon and Litopenaeus vannamei were collected from the farms and sent to our laboratory for 
Table 1. Taura syndrome virus (TSV) isolates used for experimental bioassays and sequence analysis. Sequences were retrieved as non-redundant sequences from GenBank unless otherwise indicated. Taxonomy nomenclature of penaeid shrimp is according to Farfante \& Kensley (1997)

\begin{tabular}{|c|c|c|c|c|}
\hline TSV isolate & Collection location & Source species & Collection year & GenBank no. \\
\hline Bz01 & Belize & Litopenaeus vannamei & 2001 & AY590471 \\
\hline Cn03-1 & China & L. vannamei & 2003 & AY755597 \\
\hline Cn03-2 & China & L. vannamei & 2003 & AY755598 \\
\hline Cn03-3 & China & L. vannamei & 2003 & AY755600 \\
\hline Cn03-4 & China & L. vannamei & 2003 & AY755602 \\
\hline Cn03-5 & Hainan Island, China & L. vannamei & 2003 & DQ000301 \\
\hline Er04Pm & Massawa, Eritrea & Penaeus monodon & 2004 & DQ000302 \\
\hline Id03 & Surabaya, Indonesia & L. vannamei & 2003 & DQ000303 \\
\hline $\mathrm{Mm} 03 \mathrm{Pm}$ & Myanmar & P. monodon & 2003 & AY755596 \\
\hline Mx98 & Sinaloa, Mexico & L. vannamei & 1998 & AF510515 \\
\hline Mx99 & Nayarit, Mexico & L. stylirostris & 1999 & AF510516 \\
\hline $\mathrm{Mx} 2 \mathrm{~K}$ & Sonora, Mexico & L. stylirostris & 2000 & AF510517 \\
\hline Th03-1 & Chachoengsao, Thailand & L. vannamei & 2003 & AY755587 \\
\hline Th03-2 & Ratchaburi, Thailand & L. vannamei & 2003 & AY755588 \\
\hline Th03-3 & Nakorn Pathom, Thailand & L. vannamei & 2003 & AY755591 \\
\hline Th03-4 & Nakorn Pathom, Thailand & L. vannamei & 2003 & AY755593 \\
\hline Th03-5 & Samut Sakorn, Thailand & L. vannamei & 2003 & DQ000304 \\
\hline Th03-6 & Chachoengsao, Thailand & L. vannamei & 2003 & DQ000305 \\
\hline Th04Lv ${ }^{\mathrm{a}}$ & Chumporn, Thailand & L. vannamei & 2004 & AY997025 \\
\hline Th04Pm ${ }^{\mathrm{a}}$ & Chachoengsao, Thailand & P. monodon & 2004 & DQ000306 \\
\hline Tw2KMe & Taiwan & Metapenaeus ensis & 2000 & AY355310 \\
\hline Tw2KPm & Taiwan & P. monodon & 2000 & AY355309 \\
\hline Tw99 & Taiwan & L. vannamei & 1999 & AF406789 \\
\hline UsHi94 & Hawaii, USA & L. vannamei & 1994 & AF277675 \\
\hline
\end{tabular}

diagnosis. We detected the presence of TSV in these samples by traditional RT-PCR and real-time RT-PCR (Nunan et al. 1998, Tang et al. 2004). We did not detect the presence of any other pathogens of concern to penaeid shrimp in these samples (data not shown). To determine if these $2 \mathrm{TSV}$ isolates, Th04PmTSV and Th04LvTSV (Table 1), contained infectious TSV, we performed bioassays with groups of $P$. monodon (obtained from a shrimp producer) and specific pathogen free (SPF) (Lotz 1997) Kona stock L. vannamei (Oceanic Institute). These shrimp were tested and determined to be free of TSV before use. The bioassays comprised 3 experimental groups: Groups 1 and 2 served as the test groups, whereas Group 3 served as the negative control. Each group had 1 aquarium for $P$. monodon (10 shrimp, avg. wt $=3 \mathrm{~g}$ ) and another for L. vannamei $(10$ shrimp, avg. wt $=1 \mathrm{~g})$. Each shrimp in Group 1 was administered a single injection $(\sim 100 \mu \mathrm{l})$, into their third tail segment, of a tissue homogenate prepared from frozen TSV-infected P. monodon (Th04PmTSV), whereas each shrimp in Group 2 was injected $(\sim 100 \mu \mathrm{l})$ with a tissue homogenate prepared from frozen TSV-infected L. vannamei (Th04LvTSV). The tissue homogenates were prepared from shrimp heads as described by Hasson et al. (1995), and diluted 1:10 with 2\% saline prior to inoculation. Shrimp in Group 3 were not exposed to TSV. All of the shrimp were fed once a day with a commercial pellet feed (Rangen $35 \%$; Buhl), for 28 d. On Days 2 and 14 post-inoculation (p.i.), 2 shrimp were sampled from each test group. At termination of the experiment (28 d p.i.), all of the survivors were

Table 2. Penaeus monodon and Litopenaeus vannamei. Initial appearance of dead shrimp and cumulative mortality after TSV infection. Cumulative mortality: no. of dead shrimp at Day 28 post-inoculation (p.i.), 2 shrimp removed at Days 2 and 14 p.i. for analyses; 10 shrimp per tank were stocked at Day 0 p.i. TSV infection determined by H\&E histological, in situ hybridization, and RT-PCR analyses

\begin{tabular}{|c|c|c|c|c|}
\hline Group & Species & $\begin{array}{l}\text { Day of } \\
\text { first death }\end{array}$ & $\begin{array}{c}\text { Cumulative } \\
\text { mortality }\end{array}$ & TSV infection \\
\hline \multirow[t]{2}{*}{$1^{\mathrm{a}}$} & P. monodon & 3 & 2 & Positive \\
\hline & L. vannamei & 2 & 8 & Positive \\
\hline \multirow[t]{2}{*}{$2^{\mathrm{b}}$} & P. monodon & 3 & 2 & Positive \\
\hline & L. vannamei & 2 & 8 & Positive \\
\hline \multirow[t]{2}{*}{$3^{c}$} & P. monodon & No death & 0 & Negative \\
\hline & L. vannamei & No death & 0 & Negative \\
\hline
\end{tabular}




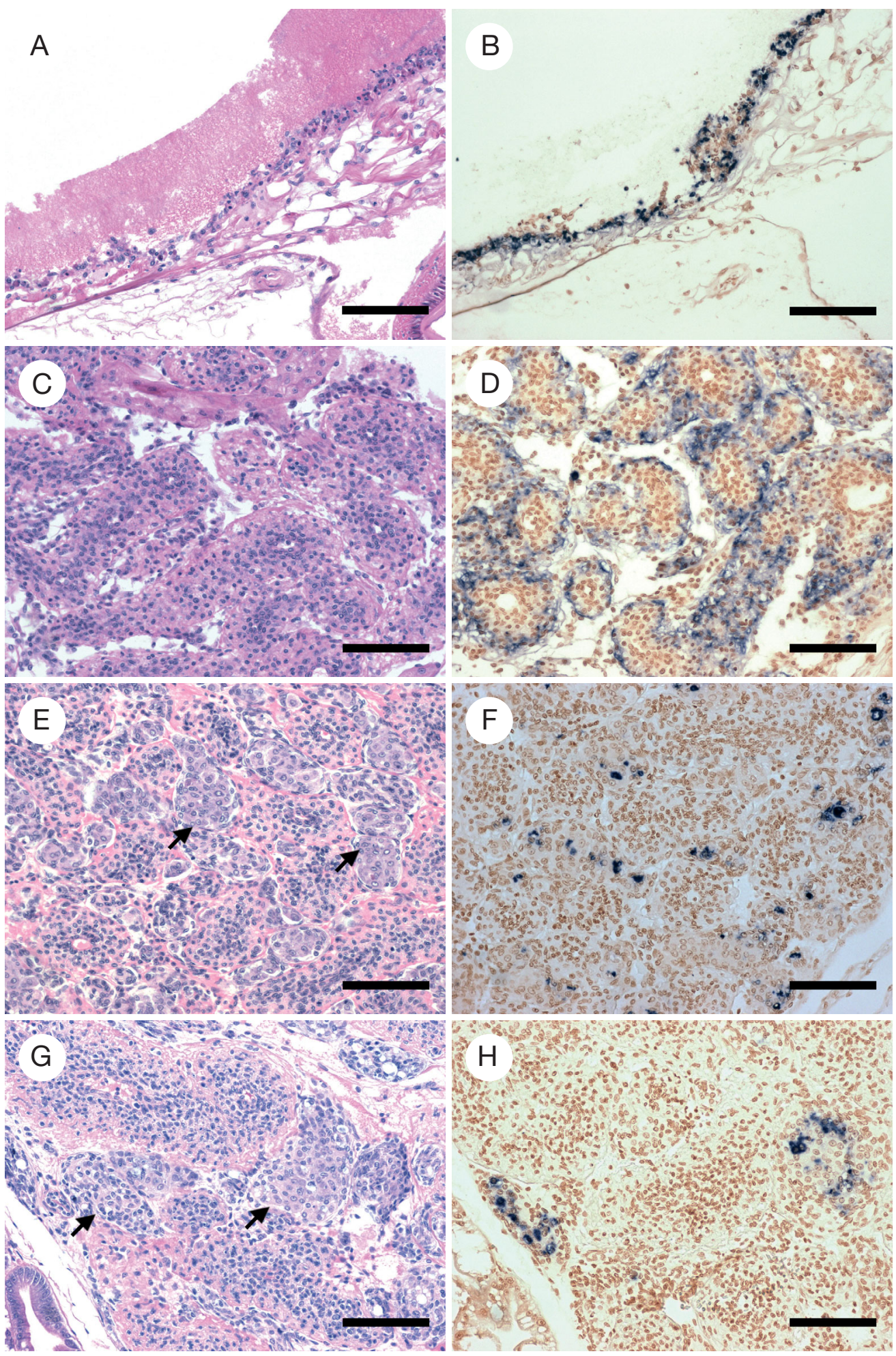

Fig. 1. Penaeus monodon. Photomicrographs of consecutive hematoxylin and eosin (H\&E) stained (left column) and in situ hybridization (ISH) gene probes (right column) tissue sections illustrating Taura syndrome virus (TSV) lesions. (A,B) Cuticular epithelium with acute phase lesions in a specimen collected at Day 2 post-inoculation (p.i.); note severe necrosis of infected epithelial cells by H\&E and blue-black precipitates by in situ hybridization (ISH). (C, D) Lymphoid organ of the same specimen; note normal appearance by H\&E but blue-black precipitates at the peripheries of lymphoid tubules by ISH. (E - H) Lymphoid organ in specimens collected at Days $14(\mathrm{E}, \mathrm{F})$ and $28(\mathrm{G}, \mathrm{H})$ p.i.; note lymphoid organ spheroids (arrowed) by H\&E and blue-black precipitates by ISH. Scale bars $=50 \mu \mathrm{m}$ 


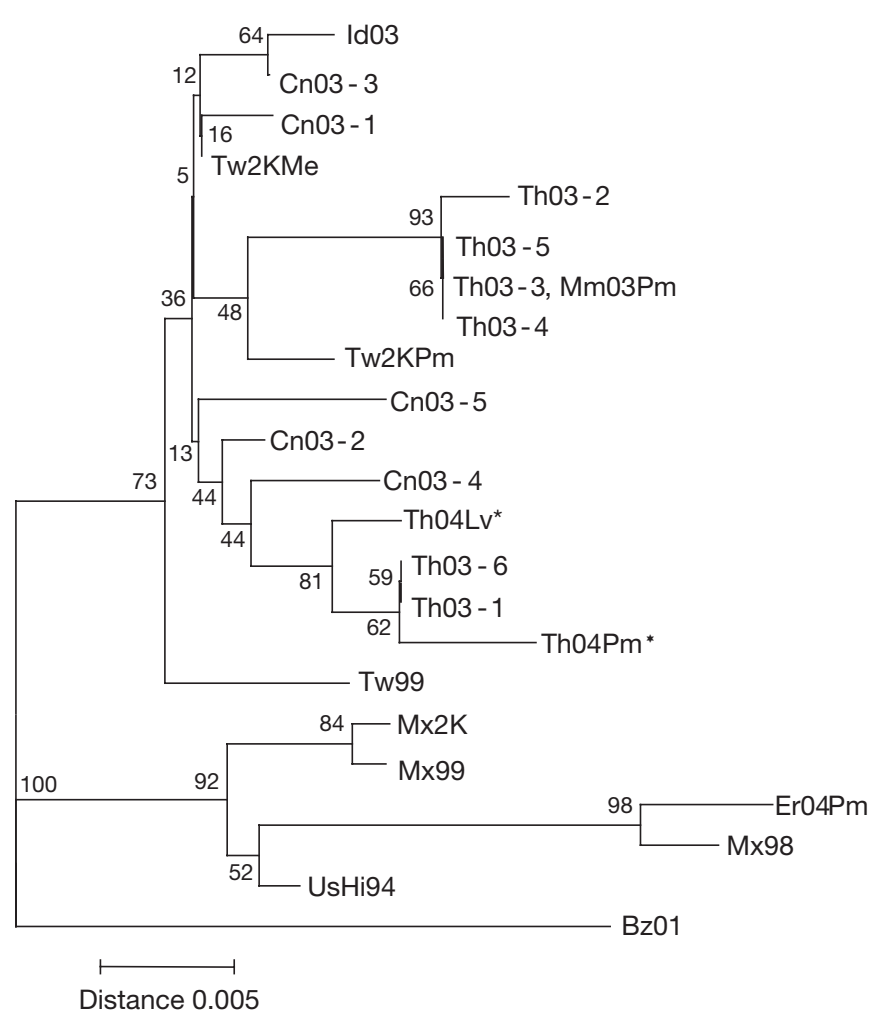

Fig. 2. Phylogenetic neighbor-joining (NJ) tree of capsid protein 2 (CP2) protein (383 amino acids) from 24 TSV isolates. Numbers on branches represent bootstrap values (\%) after 1000 replicates. *: isolates used in our experimental bioassays

sampled. The tails of sampled shrimp were frozen at $-70^{\circ} \mathrm{C}$ for RT-PCR (Nunan et al. 1998, data not shown), whereas the heads were fixed overnight in Davidson's fixative and transferred to $70 \%$ alcohol for hematoxylin and eosin (H\&E) histological examination and ISH analyses (Lightner 1996, Mari et al. 1998). We used a mixture of probes Q1 and P15 that hybridize the TSV genome at nucleotides 3218 to 4139 and 5915 to 7140 , respectively, for ISH (Mari et al. 1998).

Sequence analyses. We extracted total RNA, from either pleopods or gills of the shrimp samples, using a High Pure RNA tissue kit (Roche Biochemical) according to the manufacturer's instructions. RT-PCR was performed using a SuperScript one-step RT-PCR system with Platinum Taq DNA polymerase (Invitrogen). The capsid protein 2 (CP2) region (nucleotides 7901 to 9203) of the TSV genome was amplified with primers 55P1 (5'-GGC GTA GTG AGT AAT GTA GC-3') and 55P2 (5'-CTT CAG TGA CCA CGG TAT AG-3') (Erickson et al. 2002). The RT-PCR profile was $30 \mathrm{~min}$ at $50^{\circ} \mathrm{C}$, followed by 40 cycles of $30 \mathrm{~s}$ at $94^{\circ} \mathrm{C}, 30 \mathrm{~s}$ at $55^{\circ} \mathrm{C}$, and $1.5 \mathrm{~min}$ at $68^{\circ} \mathrm{C}$. An aliquot of amplified product was analyzed in a $1 \%$ agarose gel containing ethidium bromide. The amplified product of CP2 was cleaned with a QIA Quick PCR purification kit (Qiagen) and sequenced from both strands with an automated DNA sequencer, ABI Prism 377 (Applied Biosystems) at the sequencing facility, University of Arizona. Nucleotide sequences were aligned with Sci Ed Central software (Scientific \& Educational Software), and the correct nucleotide sequences were determined. Multiple alignments of the deduced CP2 amino acid sequences (383 amino acids) from 24 TSV isolates (Table 1) were analyzed by CLUSTAL X (Thompson et al. 1997) and GeneDoc software (Nicholas et al. 1997). Phylogenetic analysis based on the neighbor-joining (NJ) methods of these TSV isolates was performed at 1000 bootstrap replicates using MEGA software (Kumar et al. 2001).

\section{RESULTS AND DISCUSSION}

\section{Mortalities and lesions of TSV infection in Penaeus monodon}

To study TSV infection in Penaeus monodon as well as Litopenaeus vannamei, we performed experimental bioassays using 2 Thai TSV isolates: Th04PmTSV and Th04LvTSV (Table 1). For both virus isolates, inoculated $P$. monodon showed mortalities at Day 3 postinoculation (p.i.), with 2 out of 10 shrimp dying and all other shrimp surviving for the rest of the study (Table 2). For L. vannamei, mortalities first appeared at Day 2, with 8 out of 10 shrimp dying by Day 6 p.i. These results may be because (1) L. vannamei (avg. $\mathrm{wt}=1 \mathrm{~g}$ ) received a larger (3 times more) dose of tissue homogenate by weight than did $P$. monodon (avg. wt $=$ $3 \mathrm{~g}$ ), or (2) L. vannamei were less tolerant to TSV than $P$. monodon. No mortality was observed among $P$. monodon or L. vannamei in the negative control group (Group 3).

Penaeus monodon developed lesions when injected with Th04PmTSV. One of 2 specimens (sampled at Day 2 p.i.) showed characteristic acute phase lesions of TSV infection (Hasson et al. 1995, Lightner et al. 1995), indicated by severe necrosis in various epithelial tissues, including gills and cuticular and stomach epithelia (Fig. 1A). When the consecutive tissue section of this shrimp was analyzed using ISH, a positive reaction to TSV-specific gene probes was detected as blueblack precipitates (Fig. 1B). This specimen exhibited a normal lymphoid organ by histology (Fig. 1C). However, using ISH, its consecutive lymphoid organ section displayed a strong positive reaction, and the reaction was seen only at the peripheral sheath cells of lymphoid organ tubules (Fig. 1D). The same lesion was also seen in Litopenaeus vannamei at the early transition phase of TSV infection through ISH (Hasson et al. 1999b). Moreover, a somewhat similar lesion was also 


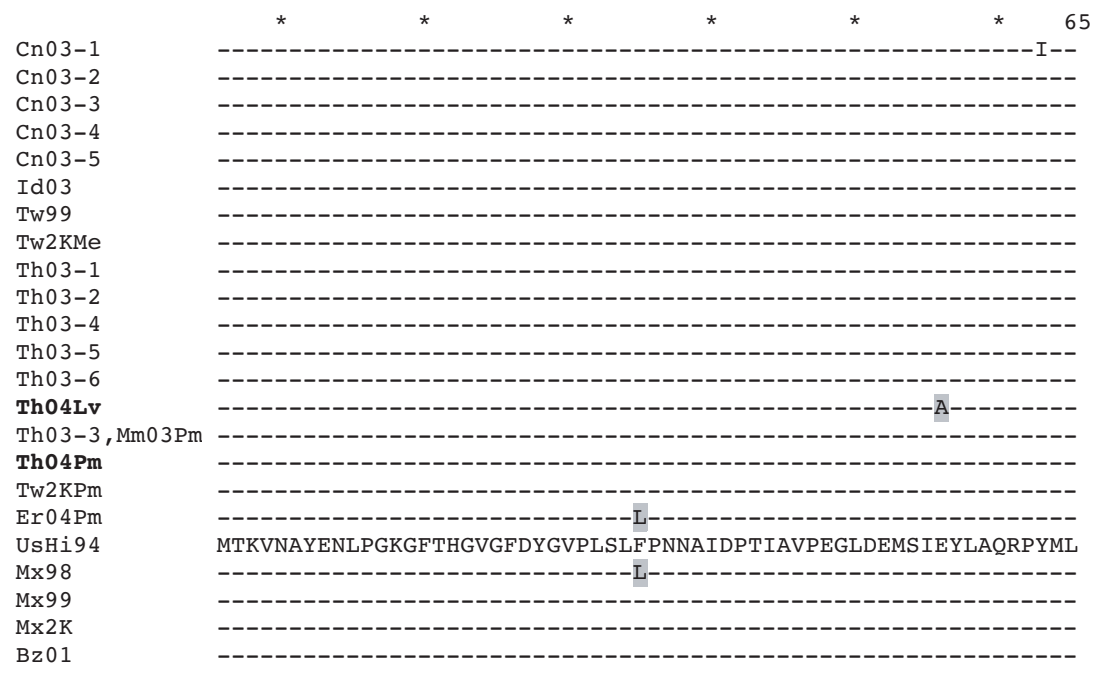

Cn03-1

Cn03-2

Cn03-3

Cn03-4

Cn03-5

Id03

Tw99

Tw2 KMe

Th03-1

Th03-2

Th03-4

Th03-5

Th03-6

Th04Lv

Th03-3, Mm0 3Pm

Th04 Pm

Tw2 KPm

Er0 4 Pm

UsHi94

Mx98

Mx99

$\mathrm{Mx} 2 \mathrm{~K}$

$\mathrm{Bz} 01$

Cn03-1

Cn03-2

Cn03-3

Cn03-4

Cn03-5

Id03

Tw99

Tw2 KMe

Th03-1

Th03-2

Th03-4

Th03-5

Th03-6

Th04Lv

Th03-3, Mm03Pm

Th04 Pm

Tw2 KPm

Er04 Pm

UsHi94

Mx98

$\mathrm{Mx} 99$

$\mathrm{Mx} 2 \mathrm{~K}$

$\mathrm{Bz} 01$

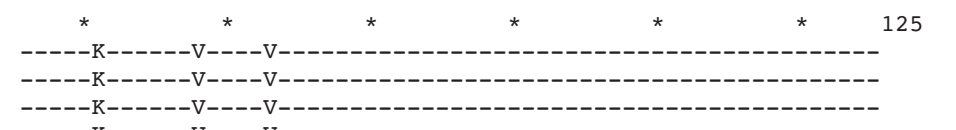

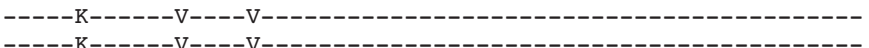

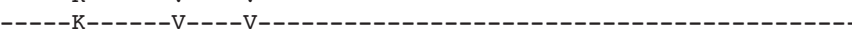

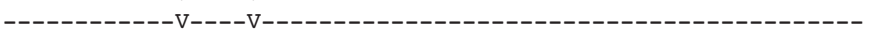

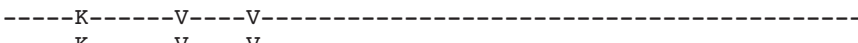

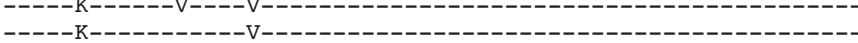

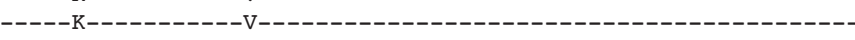

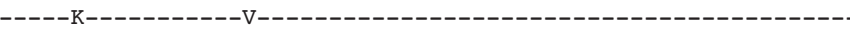

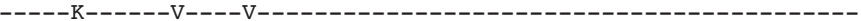

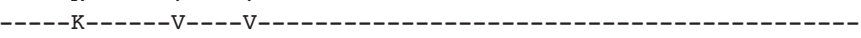

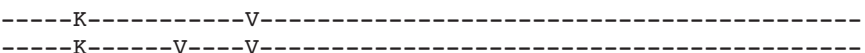

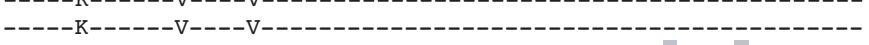
NRYTIRGGDTPDAHGTIIADIPVSPVNFSLYGKVIAKYRTLFAAPVSLAVAMANWWRGNI

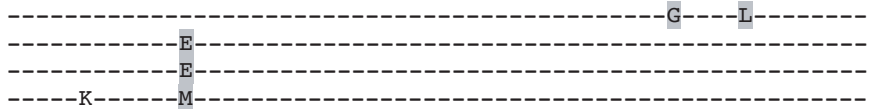

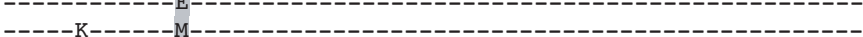

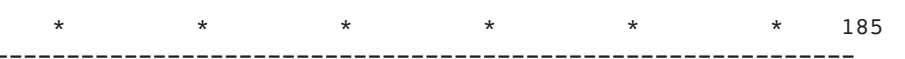

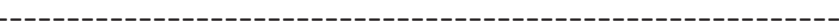

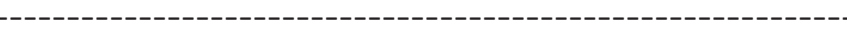

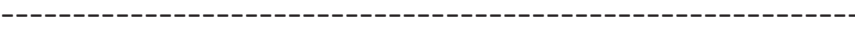

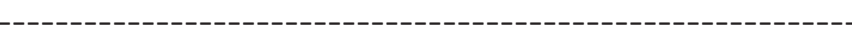

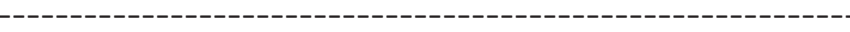

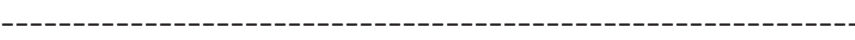

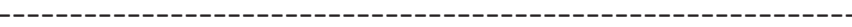

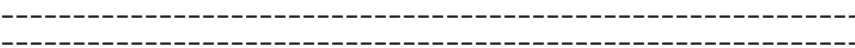

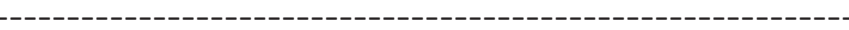

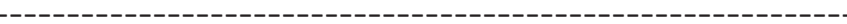

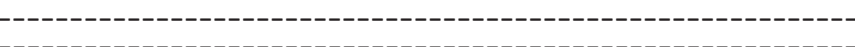

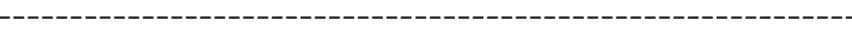

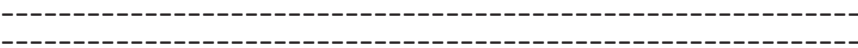

NLNLRFAKTQYHQCRLLVQYLPYGSGVQPIES ILSQI IDISQVDDKGIDIAFPSVYPNKW

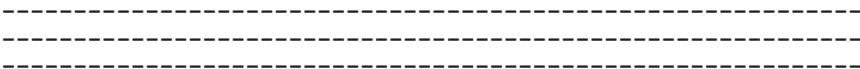

recognized in $P$. monodon infected with yellow head virus (YHV) when examined by immunohistochemistry based on a YHV-specific monoclonal antibody (Soowannaya et al. 2002). In chronic phase lesions of TSV infection, lymphoid organ spheroids (LOS) (Hasson et al. 1999b) were present in 6 specimens (2 sampled at Day 14, and 4 survivors collected at Day 28 p.i.), and consecutive lymphoid organ sections of 2 specimens 1 sampled at Day 14 and the other at Day 28 p.i.) reacted to the TSV-specific gene probes by ISH (data not shown to avoid redundancy with Fig. 1E to $\mathrm{H}$ ).

Penaeus monodon also developed lesions when injected with Th04LvTSV. LOS were detected in 3 specimens (2 sampled at Day 14 p.i., Fig. $1 E_{;} 1$ at Day 28 p.i., Fig. 1G). The consecutive lymphoid organ sections of 2 P. monodon (1 sampled at Day 14 p.i., 1 at Day 28 p.i.) reacted to the TSV-specific gene probes by ISH (Fig. 1F, H). This positive reaction indicated that LOS formation in these $P$. monodon was associated with TSV infection. Acute phase lesions of TSV infection were not detected in any $P$. monodon injected with Th04LvTSV. This result may be due to (1) an incorrect early sampling time (Day 2 p.i.), (2) the genetic characteristics of this TSV isolate, or (3) a lower inoculating dosage that resulted in a low grade acute phase infection followed by a typical chronic phase infection.

Fig. 3. Comparison of deduced amino acid sequences of CP2 from $24 \mathrm{TSV}$ isolates with reference to UsHi94 (GenBank no. AF277675). Blanks indicate amino acids identical to those in UsHi94. A grey background indicates a non-conservative amino acid difference with respect to UsHi94; normal print indicates a conservative difference. Sequence names in bold indicate the TSV strains used in our bioassays. Numbers in the alignment correspond to amino acid positions of CP2 (GenBank no. AF277675) 


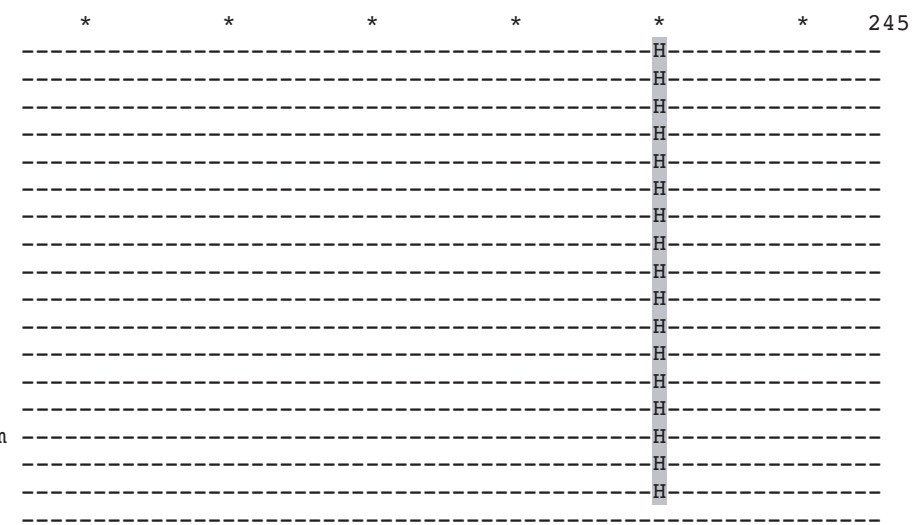

MRVYDPAKVGYTADCAPGRIVISVLNPLISASTVSPNIVMYPWVNWSNLEVAEPGTLAKA
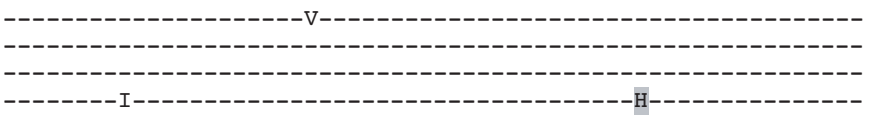

$-\mathrm{H}$

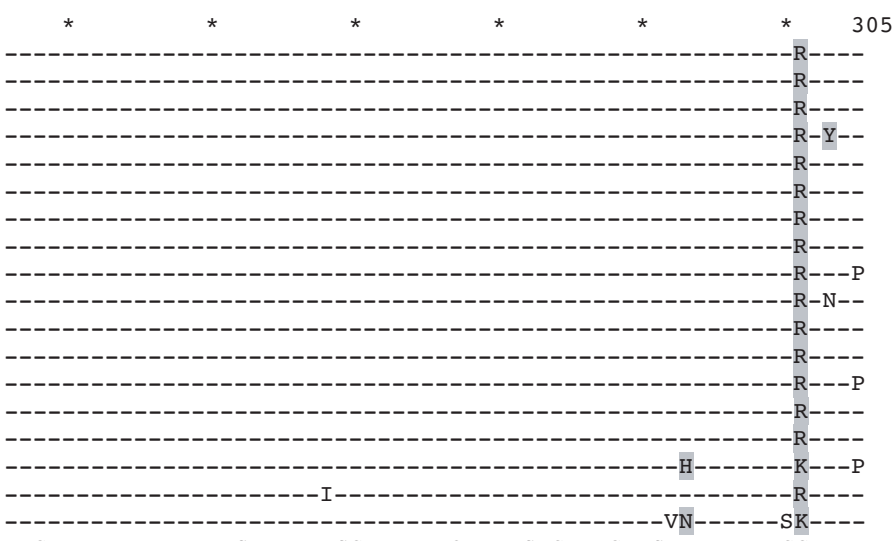
AIGFNYPADVPEEPTFSVTRAPVSGTLFTLLQDTKVSLGEADGVFSLYFTNTTTGGRHRL
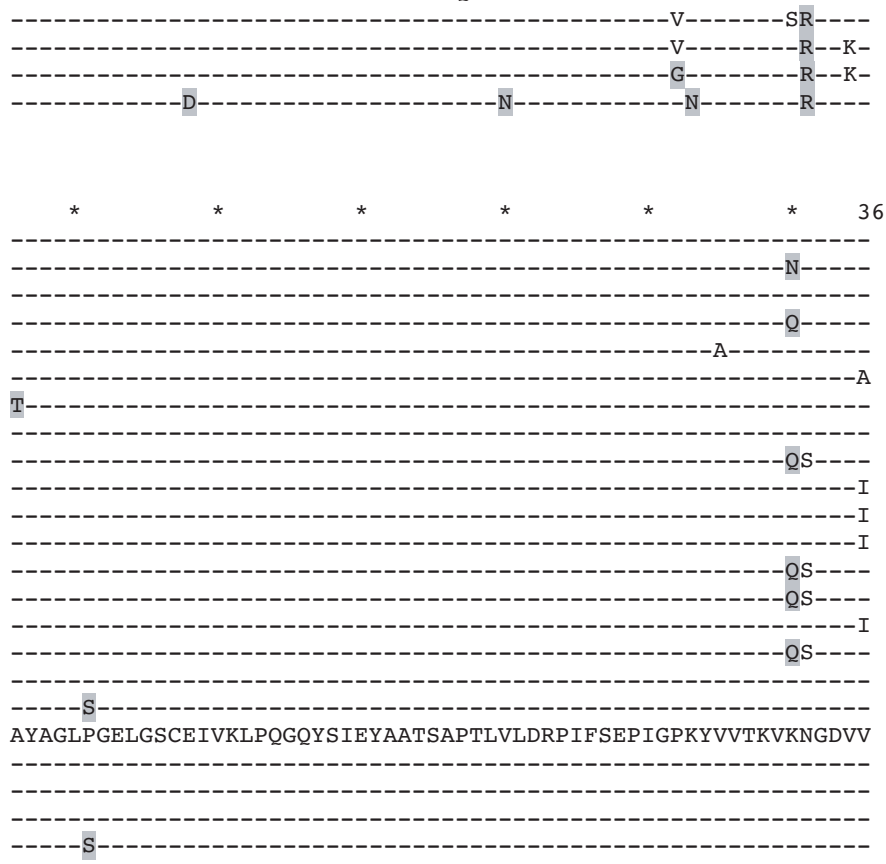

Fig. 3 (continued)
As was expected, Litopenaeus vannamei, injected with either Th04PmTSV or Th04LvTSV and sampled at Day 2 p.i., showed the acute phase lesions of TSV infection, whereas other $L$. vannamei, which were not sampled, died by Day 6 p.i. and were found to be positive for TSV by RT-PCR (data not shown). At termination of the experiment (Day 28 p.i.), lesions indicative of TSV infection, as described by Lightner et al. (1995), and Hasson et al. $(1995,1999 b)$, were not detected in any P. monodon or L. vannamei in the negative control group (data not shown).

\section{Sequence analyses of Th04PmTSV and Th04LvTSV}

We sequenced the CP2 gene of the 2 isolates Th04PmTSV and Th04LvTSV from their original tissue samples. These 2 TSV isolates were found to be different by $1.5 \%$ in the amino acid sequence. Phylogenetic analysis of 24 TSV isolates (Fig. 2) also revealed that $\mathrm{Th} 04 \mathrm{Pm}$ and Th04Lv were 2 distinct isolates although both belong to a phylogenetic family of Asian TSV isolates. This result was consistent with each isolate being collected from geographically distant locations in Thailand. Comparison of amino acid similarities of these 24 TSV isolates, according to Poch et al. 1990, revealed that the CP2 amino acid variations at positions 71, 83, 230, 301, and 366 may act as genetic markers of Asian TSV isolates because they were found in many TSV isolates collected from China, Indonesia, Taiwan, and Thailand (Fig. 3). The phylogenetic tree also showed that Er04PmTSV isolate formed a cluster with the Mx98TSV isolate (Fig. 2); the Er04PmTSV isolate was collected from a farm in Eritrea in which both Penaeus monodon and Litopenaeus vannamei were cultured and found to be infected with TSV (D. V. Ligthner unpubl. data). The results from the 


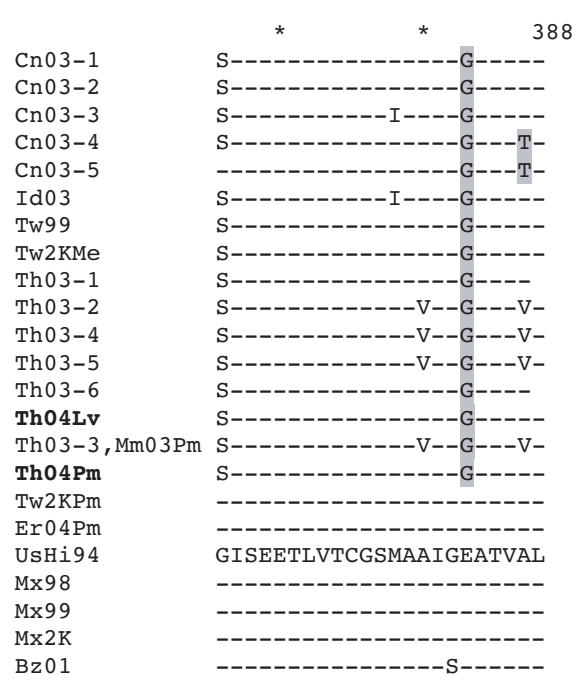

Fig. 3 (continued)

sequence analyses (Figs. 2 \& 3) also suggest that TSV sequences from $P$. monodon and $L$. vannamei from the same area tend to resemble each other. In other words, $P$. monodon appear to be susceptible to any TSV types that are prevalent in the area where they are cultivated.

In conclusion, Penaeus monodon was found to be susceptible to TSV. Using experimental bioassays, we provide the first evidence of TSV infection in $P$. monodon by histological and ISH analyses. TSV may also be an important pathogen in P. monodon, as observed in Thailand and Eritrea because of the ability of the virus to produce persistent chronic (carrier) infections in the species and because of its potential to cause mortalities under some conditions. Finally, our results indicated that additional studies are needed to elucidate the prevalence and role of TSV in P. monodon aquaculture.

Acknowledgements. This work was supported by Gulf Coast Research Laboratory Consortium Marine Shrimp Farming Program, CSREES, USDA, Grant no. 2002-38808-01345. We thank Mr. Robins McIntosh (Charoen Pokapand, Thailand) for providing the shrimp tissues infected with Th04PmTSV and Th04LvTSV.

\section{LITERATURE CITED}

Bonami JR, Hasson KW, Mari J, Poulos BT, Lightner DV (1997) Taura syndrome of marine penaeid shrimp: characterization of the viral agent. J Gen Virol 78:313-319

Chang YS, Peng SE, Yu HT, Liu FC, Wang CH, Lo CF, Kou GH (2004) Genetic and phenotypic variations of isolates of shrimp Taura syndrome virus found in Penaeus monodon and Metapenaeus ensis in Taiwan. J Gen Virol 85: 2963-2968

Erickson HS, Zarain-Herzberg M, Lightner DV (2002) Detection of Taura syndrome virus (TSV) strain differences using selected diagnostic methods: diagnostic implications in penaeid shrimp. Dis Aquat Org 52:1-10
Farfante P Kensley BF (1997) Penaeoid and sergestoid shrimp and prawns of the world: keys and diagnoses for the families and genera. Mem Mus Natl Hist Nat 175:1-233

Hasson KW, Lightner DV, Poulos BT, Redman RM, White BL, Brock JA, Bonami JR (1995) Taura syndrome in Penaeus vannamei: demonstration of a viral etiology. Dis Aquat Org 23:115-126

Hasson KW, Lightner DV, Mari J, Bonami JR, Poulos BT, Mohney LL, Redman RM, Brock JA (1999a) The geographic distribution of Taura syndrome virus (TSV) in the Americas: determination by histopathology and in situ hybridization using TSV specific cDNA probes. Aquaculture 171:13-26

Hasson KW, Lightner DV, Mohney LL, Redman RM, White BM (1999b) Role of lymphoid organ spheroids in chronic Taura syndrome virus (TSV) infections in Penaeus vannamei. Dis Aquat Org 38:93-105

Jimenez R (1992) Simdrome de Taura (Resumen). Acuacultura del Ecuador 1:1-16

Kumar S, Tamura K, Jakobsen IB, Nei M (2001) MEGA: Molecular Evolutionary Genetics Analysis, version 2.1. Bioinformatics 17:1244-1245

Lightner DV (1996) A handbook of shrimp pathology and diagnostic procedures for diseases for cultured penaeid shrimp. World Aquaculture Society, Baton Rouge, LA

Lightner DV, Redman RM, Hasson KW, Pantoja CR (1995) Taura syndrome in Penaeus vannamei (Crustacea: Decapoda): gross signs, histopathology and ultrastructure. Dis Aquat Org 21:53-59

Lotz JM (1997) Special topic review: viruses, biosecurity, and specific pathogen-free stocks in shrimp aquaculture. World J Microbiol Biotechnol 13:405-413

Mari J, Bonami JR, Lightner DV (1998) Taura syndrome of penaeid shrimp: cloning of viral genome fragments and development of specific gene probes. Dis Aquat Org 33: $11-17$

Mari J, Poulos BT, Lightner DV, Bonami JR (2002) Shrimp Taura syndrome virus: genomic characterization and similarity with members of the genus Cricket paralysislike viruses. J Gen Virol 83:915-926

Mayo MA (2002) IVTV at the Paris ICV: results of the plenary session and the binomial ballot. Arch Virol 147:2254-2260

Mayo MA (2005) Changes to virus taxonomy 2004. Arch Virol 150:189-198

Nicholas KB, Nicholas HB Jr, Deerfield DW II (1997) GeneDoc: analysis and visualization of genetic variation. EMBNEW News 4:14

Nielsen L, Sang-oum W, Cheevadhanarak S, Flegel TW (2005) Taura syndrome virus (TSV) in Thailand and its relationship to TSV in China and the Americas. Dis Aquat Org 63:101-106

Nunan LM, Poulos BT, Lightner DV (1998) Reverse transcription polymerase chain reaction (RT-PCR) used for the detection of Taura syndrome virus (TSV) in experimentally infected shrimp. Dis Aquat Org 34:87-91

Overstreet RM, Lightner DV, Hasson KW, McIlwain S, Lotz JM (1997) Susceptibility to Taura syndrome virus of some penaeid shrimp species native to the Gulf of Mexico and the southeastern United States. J Invertebr Pathol 69: $165-176$

Poch O, Blumberg BM, Bougueleret L, Tordo N (1990) Sequence comparison of five polymerase (L proteins) of unsegmented negative strand RNA viruses: theoretical assignment of functional domains. J Gen Virol 71: 1153-1162

Soowannayan C, Sithigorngul P, Flegel TW (2002) Use of a specific monoclonal antibody to determine tissue tropism 
of yellow head virus (YHV) of Penaeus monodon by in situ immunocytochemistry. Fish Sci 68:805-809

Tang KFJ, Wang J, Lightner DV (2004) Quantitation of Taura syndrome virus by real-time RT-PCR with a TaqMan assay. J Virol Methods 115:109-114

Thompson JD, Gibson TJ, Plewniak F, Jeanmougin F, Higgins DG (1997) The CLUSTAL_X windows interface: flexible strategies for multiple sequence alignments aided by

Editorial responsibility: Timothy Flegel,

Bangkok, Thailand quality analysis tools. Nucleic Acids Res 25:4876-4882

Tu C, Huang HT, Chuang SH, Hsu JP and 6 others (1999) Taura syndrome in Pacific white shrimp Penaeus vannamei cultured in Taiwan. Dis Aquat Org 38: $159-161$

Yu CI, Song YL (2002) Outbreaks of Taura syndrome in Pacific white shrimp Penaeus vannamei cultured in Taiwan. Fish Pathol 35:21-24

Submitted: December 7, 2004; Accepted: May 8, 2005 Proofs received from author(s): September 20, 2005 